\title{
EFFECT OF SOWING DATE ON SOME AGRONOMICAL AND TECHNOLOGICAL TRAITS OF SAFFLOWER (Carthamus tinctorius L.) IN NORTHERN TURKEY
}

\author{
Naziha El BEY $Y^{l}$, Merve GORE ${ }^{2 *}$, Orhan KURT \\ ${ }^{1}$ Ondokuz Mayis University, Faculty of Agriculture, Department of Field Crops, Samsun, TURKEY. \\ ${ }^{2}$ Ege University, Odemis Vocational Training School, Department of Medicinal and Aromatic Plants, \\ Izmir, TURKEY. \\ Corresponding author: merve.gore@ege.edu.tr
}

Received:26.09.2020

\begin{abstract}
This research was conducted to determine the effect of sowing dates on some agronomical and technological traits of safflower cultivars. The research was conducted in Samsun province of Turkey during 2017-2019 growing season with the use of 4 sowing dates (30 October, 14 November, 29 November and 14 December) and two safflower cultivars (Olas and Linas). Plant heights varied between 82.3 - $158.7 \mathrm{~cm}$; number of heads per plant between 4.15 - 9.47; seed weights per head between 0.84 - $1.39 \mathrm{~g}$; thousand seed weights between 34.65 47.69 g; seed yields per plant between 3.14 - $7.67 \mathrm{~g}$; oil contents between $24.64-29.29 \%$ and oil yields per plant between $0.83-2.25 \mathrm{~g}$. According to sowing date $\mathrm{x}$ cultivar interactions, the highest agronomical and technological traits of Olas cultivar were obtained from the $2^{\text {nd }}$ sowing date and the highest values except for plant height and thousand seed yield of Linas cultivar were obtained from the $2^{\text {nd }}$ sowing date. It was concluded based on present findings that the second sowing date (14 November) was more suitable for safflower cultivation in winter season in Samsun ecological conditions.
\end{abstract}

Keywords: Carthamus tinctorius, Sowing dates, Yield, Yield components

\section{INTRODUCTION}

Safflower (Carthamus tinctorius L.) is an annual, broadleaf oilseed crop that belongs to the family Compositae or Asteraceae. It is a xeric crop tolerant to severe drought, mainly cultivated in arid and semi-arid regions of the world and constitutes an important alternative oil source (Gecgel et al., 2007). Safflower plant can be grown in summer or winter season. It was less selective than many oil plants in terms of climate and soil requirements. Safflower can grow easily in all soils, but it needs deep, fertile soils without any drainage problems to obtain high yield levels (Emongor, 2010).

Oil content of safflower seeds vary between $25-45 \%$ depending on genotype, ecology, physiology, morphology and agricultural practices. Oil quality is largely designated by the fatty acid compositions. Safflower oil is considered as a high-quality oil due to its low saturated fatty acids and high unsaturated $(90 \%)$ fatty acids mainly oleic and linoleic acids. The oil obtained from safflower is used as cooking oil and in the production of biodiesel (Baydar and Erbas, 2016).

For successful and economical safflower cultivation in any region, suitable varieties and growing techniques should be determined. Appropriate sowing date constitute a significant growing technique. Sowing date is among the most important factors designating the yield. A proper sowing data is important to ensure that vegetative growth of the plant takes place under sufficient temperature period, rainfall regime and day length.

Previous studies revealed that delayed sowing dates resulted in decreasing seed and oil yields (Samanci and Ozkaynak, 2003; Keles and Ozturk, 2012). Nikabadi et al. (2008) indicated that number of seeds per head and the seed yield decreased as the sowing date was delayed. Akhter et al. (2015) indicated that the delay in sowing led to forced maturity and low productivity due to hightemperature rates at later growth stages of crop and improper vegetative growth. Beech and Norman (1963) reported that the reduction in vegetative vigour and shortening of the reproductive phase of late sowing safflower plants contributed to the decline of seed and oil yield.

To increase the production of safflower in Turkey, high-yield cultivars should be used and appropriate agricultural practices should be applied in each region. For this purpose, this research was conducted to determine the most appropriate sowing dates of different safflower cultivars in terms of yield and primary yield components 
under ecological conditions of Samsun province of Turkey.

\section{MATERIALS AND METHODS}

Carthamus tintorius cv. Olas (oleic type) and Carthamus tintorius cv. Linas (linoleic type) safflower cultivars were used as the plant material of the present study. Field experiments were conducted in winter season of 2018 and 2019 under ecological conditions of Samsun province of Turkey $\left(41^{\circ} 22^{\prime} \quad 3.7^{\prime \prime} \mathrm{N}, \quad 36^{\circ} 11^{\prime} 53.9^{\prime \prime} \mathrm{E}\right)$. Experimental soils were clay in texture with a $\mathrm{pH}$ of 7 , rich in phosphorus and potassium and medium in organic matter (Table 1).

Table 1. Physical and chemical properties of the experiment soil

\begin{tabular}{llllll}
\hline & Physical properties & \multicolumn{3}{c}{ Chemical properties } \\
\hline Clay (\%) & 47.45 & Clay & $\mathrm{pH}$ & 7.0 & Neutral \\
Sand (\%) & 29.40 & Slightly sandy & $\mathrm{CaCo}_{3}(\%)$ & 1.22 & Limeless \\
Silt $(\%)$ & 23.15 & Slightly silty & Total salt $\left.(\mathrm{mmhos} \mathrm{cm})^{-1}\right)$ & 0.052 & Unsaline \\
& & Organic matter $(\%)$ & 2.71 & Medium \\
& & $\mathrm{P}_{2} \mathrm{O}_{5}(\mathrm{ppm})$ & 293 & High \\
& & $\mathrm{K}_{2} \mathrm{O}(\mathrm{ppm})$ & 10.34 & High \\
\hline
\end{tabular}

The data for monthly average temperature, Average precipitation was greater than the long-term precipitation and relative humidity throughout the average $(59.4 \mathrm{~mm})$ in the first year $(64.5 \mathrm{~mm})$ and lower research period and long-term averages are given in Table in the second year $(54.4 \mathrm{~mm})$. Relative humidity in both 2. The average temperature in both years (16.6 and 15.8 years $(66.1 \%$ and $70.1 \%)$ is lower than the long-term $\left.{ }^{\circ} \mathrm{C}\right)$ is higher than the long-term average $\left(14.5{ }^{\circ} \mathrm{C}\right)$. average $(72.2 \%)$ (Table 2$)$.

Table 2. Some climate data of the experiment area (2017-2018, 2018-2019 and last 55 years)

\begin{tabular}{|c|c|c|c|c|c|c|c|c|c|}
\hline \multirow[t]{2}{*}{ Months } & \multicolumn{2}{|c|}{ Temperature $\left({ }^{\circ} \mathrm{C}\right)$} & \multicolumn{4}{|c|}{ Precipitation (mm) } & \multicolumn{3}{|c|}{ Relative Humidity (\%) } \\
\hline & $\begin{array}{l}2017- \\
2018\end{array}$ & $\begin{array}{l}2018- \\
2019\end{array}$ & $\begin{array}{l}\text { Long- } \\
\text { term } \\
\text { average }\end{array}$ & $\begin{array}{l}2017- \\
2018\end{array}$ & $\begin{array}{l}2018- \\
2019\end{array}$ & $\begin{array}{l}\text { Long- } \\
\text { term } \\
\text { average }\end{array}$ & $\begin{array}{l}2017- \\
2018\end{array}$ & $\begin{array}{l}2018- \\
2019\end{array}$ & $\begin{array}{l}\text { Long- } \\
\text { term } \\
\text { average }\end{array}$ \\
\hline October & 16.4 & 18.5 & 16.3 & 34.6 & 71.4 & 81.5 & 61.6 & 69.2 & 74.3 \\
\hline November & 13.3 & 13.4 & 12.6 & 59.4 & 67.9 & 82.4 & 61.5 & 69.5 & 68.7 \\
\hline December & 12.2 & 9.9 & 9.3 & 141.1 & 76 & 82.6 & 54.5 & 64.4 & 65.6 \\
\hline January & 8.9 & 9.1 & 7.1 & 153.6 & 63.6 & 66.8 & 65.9 & 56.3 & 66.3 \\
\hline February & 10.1 & 8.5 & 7.2 & 36.8 & 37.5 & 52.8 & 71.2 & 69.2 & 68.7 \\
\hline March & 11.5 & 8.7 & 8.2 & 118.9 & 36 & 62.7 & 72.7 & 64.7 & 74.5 \\
\hline April & 12.7 & 11.7 & 11.3 & 6.8 & 66.3 & 58.2 & 69.5 & 73.4 & 77.8 \\
\hline May & 18.2 & 17.1 & 15.5 & 18.9 & 67.1 & 51.3 & 76.4 & 81.5 & 78.9 \\
\hline June & 22.9 & 23.7 & 20.1 & 29.7 & 80.4 & 47.8 & 66.5 & 77.4 & 74.3 \\
\hline July & 25.3 & 23.7 & 23.1 & 35.5 & 40.8 & 33.7 & 65.4 & 70.9 & 72.0 \\
\hline August & 25.7 & 24.3 & 23.5 & 65.3 & 18.5 & 41.5 & 61.6 & 72.5 & 71.8 \\
\hline September & 21.8 & 21.3 & 20.2 & 73.2 & 27.1 & 51.5 & 66.6 & 71.8 & 73.3 \\
\hline Total & 199 & 189.9 & 174.4 & 773.8 & 652.6 & 712.8 & 793.4 & 840.8 & 866.2 \\
\hline Average & 16.6 & 15.8 & 14.5 & 64.5 & 54.4 & 59.4 & 66.1 & 70.1 & 72.2 \\
\hline
\end{tabular}

The experiments were conducted in the randomized complete block design with 3 replications arranged in split-plot (the cultivars were placed in the main plots and the sowing dates were placed in subplots). Sowing dates were arranged as October $30^{\text {th }}$, November $14^{\text {th }}$, November $29^{\text {th }}$ and December $14^{\text {th }}$ during 2018 and 2019 winter seasons, respectively. In each plot, there were 5 rows of 3 $\mathrm{m}$ in length and $40 \mathrm{~cm}$ row spacing and $10 \mathrm{~cm}$ on-row plant spacing. During the experiments, necessary cultural practices were applied as recommended for safflower cultivation. Experimental plots were fertilized with the dose of $100 \mathrm{~kg} \mathrm{ha}^{-1}$ by DAP $(18-46 \%)$ fertilizer in the first year and ammonium nitrate $(33 \% \mathrm{~N})$ fertilizer in the second year. Fertilizers were applied at the stem elongation stage of the plant. Manual weed control was practiced on rows and a hoeing machine was used for weed control of inter-rows. Cypermethrin and Thiacloprid active substances were applied on safflower plants with a dose of $400 \mathrm{ml} \mathrm{ha}^{-1} 2$ and 3 times in the stem elongation, branching and flowering stages against broad bean (Tropinota hirta), aphid (Uroleucon compositae) and salivary beetle diseases.

Harvest was practiced in both years when the seeds of the head were physiologically mature. Side rows and 0.5 $\mathrm{m}$ sections from the top and bottom of the plots were omitted at harvest as to consider the side effects. Ten plants were randomly selected from each plot at harvest to collect data on plant height, number of heads per plant, seed weight per head and seed weight per plant. In order 
to calculate the thousand seed weight, 100 seeds were sampled for each sowing data, they were weighed and the average weight was multiplied by 10 . Oil ratio was determined with the use of a semi-automatic crude oil analyser (Ankom XT15) of Soxhlet Extraction System. Seed yield per plant was then multiplied by oil content to get oil yield per plant.

Experimental data were subjected to analysis of variance with the use of JMP 13.0 statistical software described by Carver (2019). The significance of variation was tested by the $\mathrm{F}$ test and significant means were compared with the use of TUKEY's Multiple Range Test at $5 \%$ and $1 \%$ probability levels (Gomez and Gomez, 1984).

\section{RESULTS AND DISCUSSION}

\section{Plant height}

Years, sowing dates, year $\mathrm{x}$ sowing date and cultivar $\mathrm{x}$ sowing date interactions had highly significant effects on plant heights $(\mathrm{p}<0.01)$ and year $\mathrm{x}$ cultivar interactions had significant effects on plant heights $(\mathrm{p}<0.05)$ (Table 3$)$. Average plant height was determined to be $98.79 \mathrm{~cm}$ in the first year and $135.66 \mathrm{~cm}$ in the second year (Table 4). The tallest plant height was observed in the second year probably due to the higher relative humidity $(70.1 \%)$ as compared to the first year $(66.1 \%)$ that led to plant water stress and thus reduced vegetative growth of the plant. On the other hand, despite the higher precipitation rate in the first year, the second year showed a taller plant height. Indeed, the precipitation in the second year was equally distributed over the plant growth stages, while in the first year it was concentrated in December and January at the beginning of plant growth stage when plants were in germination and rosette stage and did not need to the excess quantity of water (Table 2). The difference in plant heights of the years indicated that this parameter was greatly influenced by environmental conditions and it was characterized by a low heritability. In terms of the sowing dates, the greatest plant height $(123.42 \mathrm{~cm})$ was recorded from the $2^{\text {nd }}$ sowing date and the lowest $(111.70 \mathrm{~cm})$ was recorded from the $4^{\text {th }}$ sowing date and it was reduced by 9.5\% (Table 4). Similarly, Omidi and Sharifmogadas (2010), Hatiopoglu et al. (2012) and Ghanbari-Odivi et al. (2013) reported that the plant height of safflower decreased with delayed sowing dates. In terms of sowing date $\mathrm{x}$ year interactions, the greatest plant height (144.28 $\mathrm{cm}$ ) was obtained from the $2^{\text {nd }}$ sowing date of 2019. According to year x cultivar interactions, the greatest plant height $(136.78 \mathrm{~cm})$ was obtained from Olas cultivar in 2019 (Table 4). In terms of cultivar $x$ sowing date interactions, the greatest plant height $(134.10 \mathrm{~cm})$ was observed in the $1^{\text {st }}$ sowing date of Linas cultivar. The advanced or the delayed sowing dates had negative effects on plant heights due to the exposure of inadequate environmental conditions throughout the different growth stages.

Table 3. Analysis of variance (ANOVA) for some agronomical and technological traits of different safflower cultivars

\begin{tabular}{|c|c|c|c|c|c|c|c|c|}
\hline $\begin{array}{l}\text { Sources of } \\
\text { variation }\end{array}$ & DF & $\begin{array}{l}\text { Plant height } \\
(\mathbf{c m})\end{array}$ & $\begin{array}{c}\text { Number of } \\
\text { heads } \\
\text { (head }^{-1} \\
\text { plant) }^{\text {nata }}\end{array}$ & $\begin{array}{c}\text { Seed } \\
\text { weight } \\
\left(\mathrm{g}^{-1}\right. \\
\text { head })\end{array}$ & $\begin{array}{c}\text { Thousand seed } \\
\text { weight (g) }\end{array}$ & $\begin{array}{c}\text { Seed } \\
\text { yield } \\
\left(\mathrm{g}^{-1}\right. \\
\text { plant })\end{array}$ & $\begin{array}{c}\text { Oil } \\
\text { content } \\
(\%)\end{array}$ & $\begin{array}{c}\text { Oil } \\
\text { yield } \\
\left(\mathrm{g}^{-1}\right. \\
\text { plant })\end{array}$ \\
\hline Cultivar (V) & 1 & 4.68 & $13.66^{* *}$ & 0.57 & $17.34 * *$ & $5.81 *$ & 0.74 & $5.47 *$ \\
\hline Year $(\mathrm{Y})$ & 1 & $165.61 * *$ & $140.56^{* *}$ & $19.00 *$ & $89.76 * *$ & $57.65 * *$ & 0.17 & $44.63^{* *}$ \\
\hline Block & 4 & 0.63 & 1.47 & 0.34 & 0.54 & 2.65 & 1.98 & 1.46 \\
\hline $\mathrm{Y} \times \mathrm{V}$ & 1 & $9.55^{*}$ & $11.01 * *$ & 3.46 & 3.29 & $5.71 *$ & 2.44 & $6.03 *$ \\
\hline Error $_{1}$ & 4 & & & & & & & \\
\hline $\begin{array}{l}\text { Sowing date } \\
\text { (SD) }\end{array}$ & 3 & $12.10 * *$ & $19.58 * *$ & 2.10 & 1.91 & $18.01 * *$ & 2.49 & $20.68 * *$ \\
\hline $\mathrm{Y} \times \mathrm{SD}$ & 3 & $10.95 * *$ & $17.96 * *$ & $5.28 * *$ & $7.08 * *$ & $15.70 * *$ & 3.69 & $17.61 * *$ \\
\hline Error $_{2}$ & 12 & & & & & & & \\
\hline $\mathrm{V} \times \mathrm{SD}$ & 3 & $24.33 * *$ & $3.69 *$ & $6.21 * *$ & $8.59 * *$ & $5.87 *$ & 1.55 & $6.60 * *$ \\
\hline Y x V x SD & 3 & 2.26 & 2.09 & $7.16^{* *}$ & $7.33 * *$ & $4.99 *$ & $3.20 *$ & $7.73 * *$ \\
\hline Error3 & 12 & & & & & & & \\
\hline $\mathrm{CV}(\%)$ & & 9.66 & 9.86 & 5.22 & 5.65 & 9.70 & 6.27 & 8.36 \\
\hline
\end{tabular}

\section{Number of head}

Years, cultivars, sowing dates, year x cultivar and year $\mathrm{x}$ sowing date interactions had highly significant effects on number of heads per plant $(\mathrm{p}<0.01)$ and cultivar $\mathrm{x}$ sowing date interactions had significant effects on number of heads per plant $(\mathrm{p}<0.05)$ (Table 3$)$.

Average number of heads per plant was identified as 4.68 in the first year and 6.89 in the second year (Table 4). Number of heads per plant was higher in the second year than the first year. Variations in number of heads per plant values of the years could be due to the lower relative humidity of the first year $(66.1 \%)$ as compared to the second year $(70.1 \%)$ that led to plant water stress and thus reduced growth and production of the plant. On the other hand, despite the higher precipitation rate in the first year, the second year showed a higher number of heads per plant. Indeed, precipitation in the second year was equally distributed over the plant growth stages, while in the first year the precipitation was concentrated in two months at 
the beginning of the plant growth stage (Table 2). In terms of the sowing dates, the greatest number of heads per plant (6.97 heads) was obtained from the $2^{\text {nd }}$ sowing date and lowest $\left(5.30\right.$ heads) from the $4^{\text {th }}$ sowing date. On the other hand, Olas cultivar produced more heads (6.14 heads) than Linas cultivar (5.44 heads). Such a difference in number of heads per plant of the cultivars may have resulted from the differences in plant genetics. Greater number of heads per plant in Olas cultivar indicated that this cultivar had greater adaptability to the ecological conditions of the region. Similarly, Muhyedin et al. (2019) showed that safflower cultivars had significant effects on the number of heads per plant and such a difference may be due to varietal behaviour. Number of heads per plant is an important yield contributing parameter and has a direct effect on the final seed yield. Dajue and Mundel (1996) claimed that the number of heads per plant was strongly correlated to yield in safflower. In terms of year x cultivar interactions, the highest number of heads (7.57) was produced by Olas cultivar in the second year. According to cultivar $\mathrm{x}$ sowing date interactions, the greatest number of heads per plant (7.17) was obtained from the $2^{\text {nd }}$ sowing date of Olas cultivar. This result was supported by Badri et al. (2011) who reported that the number of heads per plant in safflower was a yield component affected by cultivar $\mathrm{x}$ sowing date interactions. However, according to year $\mathrm{x}$ sowing date interactions, the greatest number of heads ( 8.85 heads) was obtained from the $2^{\text {nd }}$ sowing date of the second year (Table 4). Kizil (2002), Emami et al. (2011), Hatipoglu et al. (2012), Seadh et al. (2012), Aslantas and Akinerdem (2019) and Barla et al. (2020) reported that the postponement of sowing date greatly reduced the number of heads per plant. In present study, number of heads per plant was significantly affected by delayed sowing dates.

\section{Seed weight}

Years had significant effects $(p<0.05)$ and year $x$ sowing date, cultivar $\mathrm{x}$ sowing date and triple interactions had highly significant effects $(\mathrm{p}<0.01)$ on seed weight per head (Table 3 ). The average seed weight per head was found to be higher $(1.29 \mathrm{~g})$ in the first year than in the second year $(1.10 \mathrm{~g})$ due to the lower number of heads and the different climate conditions during the seed filling phase. The data revealed that the effect of sowing date on seed weight per head was insignificant. Contrary, it was reported that the delay of sowing date had negative effects on the seed weight per head and that this parameter increased with the first sowing (Seadh et al., 2012). According to year $\mathrm{x}$ sowing date interactions, the greatest seed weight per head $(1.41 \mathrm{~g})$ was obtained from the $4^{\text {th }}$ sowing date of the first year. On the other hand, in terms of cultivar $\mathrm{x}$ sowing date interactions, the greatest seed weight per head $(1.39 \mathrm{~g})$ was obtained from the $2^{\text {nd }}$ sowing date of Olas cultivar. In terms of the triple interactions, the greatest seed weight per head $(1.51 \mathrm{~g})$ was recorded from the $2^{\text {nd }}$ sowing date of Olas cultivar in 2019 (Table 4).

\section{Thousand seed weight}

Years, cultivars, year $\mathrm{x}$ sowing date, cultivar $\mathrm{x}$ sowing date and triple interactions had highly significant effects on thousand seed weight $(\mathrm{p}<0.01)$ (Table 3$)$. Across the years, the second year gave the highest thousand seed weight $(45.58 \mathrm{~g})$ as compared to the first year (38.91 g). Variations in the thousand seed weight of two years could be due to environmental conditions. On the other hand, higher plant height and higher number of heads per plant in the second year had positive contributions to thousand seed weight. Mohammadzadeh et al. (2011) emphasized that delayed sowing dates shortened grain-fill period and thus decreased thousand seed weights due to lower dry matter accumulation in seed. Differences in thousand seed weights of the sowing dates were not found to be significant and such a finding comply with the results of Sirel and Aytac (2016) and Tayebi et al. (2012). Linas cultivar produced significantly higher thousand seed weight (43.69 g) than Olas cultivar (40.79 g). This difference may have resulted from differences in genetic structure of the cultivars. It was emphasized that thousand seed weight was the best selection criterion to improve seed yield in safflower (Hussain et al., 2014). In terms of year $\mathrm{x}$ sowing date interactions, the greatest thousand seed weight $(47.69 \mathrm{~g})$ was obtained from the $2^{\text {nd }}$ sowing date of 2019. According to cultivar $x$ sowing date interactions, the greatest thousand seed weight $(45.98 \mathrm{~g})$ was obtained from the $2^{\text {nd }}$ sowing date of Linas cultivar. Present thousand seed weights ranged from 34.65 to $51.08 \mathrm{~g}$ with an average value of $42.24 \mathrm{~g}$. Present findings comply with the results of La Bella et al. (2019) (between 36.66-43.25 g) and Sirel and Aytac (2016) (between 29.60-45.05 g). Regarding the triple interactions, the greatest thousand seed weight $(51.08 \mathrm{~g})$ was recorded from the $2^{\text {nd }}$ sowing date of Linas cultivar in 2019 (Table 4). Thousand seed weight was reported as an additive genetic character and least influenced by the environment (Camas and Esendal, 2006). It was indifferent from the delay in the sowing date. These results are similar to those reported by Cosge and Kaya (2008) and Tayebi et al. (2012). However, Mohamadzadeh et al. (2011) showed that the postponement of the sowing date resulted in shortening of seed filling period and thus in a decrease of thousand seed weight due to the low dry matter accumulation in the seed.

\section{Seed yield}

Years, sowing dates and year $x$ sowing date interactions had highly significant $(\mathrm{p}<0.01)$ and cultivars, year $\mathrm{x}$ cultivar, cultivar $\mathrm{x}$ sowing date and triple interactions had significant $(\mathrm{p}<0.05)$ effects on seed yields (Table 3$)$. The second year had greater seed yield $\left(5.32 \mathrm{~g}^{-1}\right.$ plant) than the first year (3.97 $\mathrm{g}^{-1}$ plant). Olas cultivar produced significantly higher seed yield (4.87 $\mathrm{g}^{-1}$ plant) than Linas cultivar (4.42 $\mathrm{g}^{-1}$ plant). Besides, according to year $x$ cultivar interactions, the highest seed yield $\left(5.77 \mathrm{~g}^{-1}\right.$ plant) was obtained from Olas cultivar in 2019 (Table 4). In terms of the sowing dates, the greatest seed yield per plant $(5.72 \mathrm{~g})$ was obtained from the $2^{\text {nd }}$ sowing date and no difference was seen between the other sowing dates (Table 4). 
Table 4. Some agronomical and technological traits of two different safflower cultivars and Duncan groups for these traits

\begin{tabular}{|c|c|c|c|c|c|c|c|c|c|}
\hline \multicolumn{3}{|c|}{ Factors } & $\begin{array}{l}\text { Plant height } \\
(\mathrm{cm})\end{array}$ & $\begin{array}{c}\text { Number of } \\
\text { heads } \\
\text { (head }^{-1} \\
\text { plant) }\end{array}$ & $\begin{array}{c}\text { Seed } \\
\text { weight } \\
\left(\mathrm{g}^{-1}\right. \\
\text { head })\end{array}$ & $\begin{array}{c}\text { Thousand seed } \\
\text { weight }(\mathrm{g})\end{array}$ & $\begin{array}{c}\text { Seed } \\
\text { yield } \\
\left(\mathrm{g}^{-1}\right. \\
\text { plant })\end{array}$ & $\begin{array}{c}\text { Oil } \\
\text { content } \\
(\%)\end{array}$ & $\begin{array}{c}\text { Oil } \\
\text { yield } \\
\left(\mathrm{g}^{-1}\right. \\
\text { plant })\end{array}$ \\
\hline \multicolumn{10}{|l|}{ Year } \\
\hline \multicolumn{3}{|l|}{2018} & $98.79 b$ & $4.68 b$ & $1.29 \mathrm{a}$ & $38.91 b$ & $3.97 \mathrm{~b}$ & 26.11 & $1.04 \mathrm{~b}$ \\
\hline \multicolumn{3}{|l|}{2019} & $135.66 \mathrm{a}$ & $6.89 \mathrm{a}$ & $1.10 \mathrm{~b}$ & $45.58 \mathrm{a}$ & $5.32 \mathrm{a}$ & 26.22 & $1.41 \mathrm{a}$ \\
\hline \multicolumn{10}{|c|}{ Cultivar } \\
\hline \multicolumn{3}{|c|}{ Olas } & 114.33 & $6.14 \mathrm{a}$ & 1.19 & $40.79 b$ & $4.87 \mathrm{a}$ & 26.28 & $1.29 \mathrm{a}$ \\
\hline \multicolumn{3}{|l|}{ Linas } & 120.13 & $5.44 \mathrm{~b}$ & 1.20 & $43.69 \mathrm{a}$ & $4.42 \mathrm{~b}$ & 26.04 & $1.16 \mathrm{~b}$ \\
\hline \multicolumn{10}{|c|}{ Sowing date } \\
\hline \multicolumn{3}{|c|}{$1 . \mathrm{SD}$} & $119.64 \mathrm{ab}$ & $5.52 \mathrm{~b}$ & 1.22 & 42.21 & $4.35 b$ & 26.11 & $1.15 b$ \\
\hline \multicolumn{3}{|l|}{ 2.SD } & $123.42 \mathrm{a}$ & $6.97 \mathrm{a}$ & 1.24 & 43.33 & $5.72 \mathrm{a}$ & 26.95 & $1.55 \mathrm{a}$ \\
\hline \multicolumn{3}{|l|}{ 3.SD } & $114.15 b$ & $5.37 \mathrm{~b}$ & 1.10 & 42.13 & $4.06 \mathrm{~b}$ & 25.85 & $1.05 b$ \\
\hline \multicolumn{3}{|l|}{ 4.SD } & $111.70 \mathrm{~b}$ & $5.30 \mathrm{~b}$ & 1.21 & 41.30 & $4.45 b$ & 25.74 & $1.15 b$ \\
\hline \multicolumn{10}{|l|}{$\mathbf{Y} \times \mathbf{V}$} \\
\hline \multirow{2}{*}{2018} & \multicolumn{2}{|c|}{ Olas } & $91.88 \mathrm{c}$ & $4.71 \mathrm{c}$ & 1.31 & 36.91 & $3.97 \mathrm{c}$ & 26.01 & $1.03 \mathrm{c}$ \\
\hline & \multicolumn{2}{|c|}{ Linas } & $105.71 b$ & $4.66 \mathrm{c}$ & 1.27 & 40.90 & $3.97 \mathrm{c}$ & 26.20 & $1.04 \mathrm{c}$ \\
\hline \multirow{2}{*}{2019} & \multicolumn{2}{|c|}{ Olas } & $136.78 \mathrm{a}$ & $7.57 \mathrm{a}$ & 1.07 & 44.67 & $5.77 \mathrm{a}$ & 26.56 & $1.55 \mathrm{a}$ \\
\hline & Linc & & $134.55 \mathrm{a}$ & $6.22 \mathrm{~b}$ & 1.13 & 46.49 & $4.87 \mathrm{~b}$ & 25.88 & $1.27 \mathrm{~b}$ \\
\hline $\mathbf{Y} \times \mathrm{S}$ & & & & & & & & & \\
\hline & 1.SI & & $95.92 \mathrm{c}$ & $4.27 \mathrm{de}$ & $1.20 \mathrm{ab}$ & $37.36 \mathrm{~d}$ & 3.34de & 25.42 & $0.85 \mathrm{~d}$ \\
\hline & 2.SI & & $102.55 \mathrm{c}$ & $5.09 \mathrm{de}$ & $1.27 \mathrm{ab}$ & $38.97 \mathrm{~cd}$ & $4.63 b c$ & 26.37 & $1.22 b c$ \\
\hline & 3.SI & & $97.57 \mathrm{c}$ & $4.18 \mathrm{e}$ & $1.27 \mathrm{ab}$ & $41.32 b c$ & $3.14 \mathrm{e}$ & 26.33 & $0.83 \mathrm{~d}$ \\
\hline 2018 & 4.SI & & $99.13 \mathrm{c}$ & $5.20 \mathrm{de}$ & $1.41 \mathrm{a}$ & $37.98 \mathrm{~cd}$ & $4.77 b c$ & 26.30 & $1.25 \mathrm{bc}$ \\
\hline & 1.SI & & $143.37 \mathrm{a}$ & $6.76 b$ & $1.24 \mathrm{ab}$ & $47.06 \mathrm{a}$ & $5.35 b$ & 26.80 & $1.45 b$ \\
\hline & 2.SI & & $144.28 \mathrm{a}$ & $8.85 a$ & $1.21 \mathrm{ab}$ & $47.69 \mathrm{a}$ & $6.81 \mathrm{a}$ & 27.53 & $1.89 \mathrm{a}$ \\
\hline 2019 & 3.SI & & $130.73 \mathrm{ab}$ & $6.56 b c$ & $0.93 c$ & $42.94 b$ & $4.99 b c$ & 25.38 & $1.27 \mathrm{bc}$ \\
\hline & 4.SI & & $124.27 \mathrm{~b}$ & $5.40 \mathrm{~cd}$ & $1.02 \mathrm{bc}$ & $44.62 \mathrm{ab}$ & $4.13 \mathrm{~cd}$ & 25.17 & $1.04 \mathrm{~cd}$ \\
\hline $\mathrm{V} \times \mathrm{S}$ & & & & & & & & & \\
\hline & $1 . \mathrm{S}$ & & $105.18 b$ & $5.51 \mathrm{bcd}$ & $1.14 \mathrm{ab}$ & $39.38 \mathrm{c}$ & $4.04 \mathrm{~cd}$ & 25.44 & $1.03 \mathrm{~cd}$ \\
\hline & $2 . S$ & & $118.47 \mathrm{bc}$ & $7.17 \mathrm{a}$ & $1.39 \mathrm{a}$ & $40.68 c$ & $6.01 \mathrm{a}$ & 27.54 & $1.68 \mathrm{a}$ \\
\hline Olas & $3 . S$ & & $116.00 \mathrm{bcd}$ & $5.90 \mathrm{a}-\mathrm{d}$ & $1.06 \mathrm{~b}$ & $41.83 b c$ & $4.51 \mathrm{bcd}$ & 25.92 & $1.17 \mathrm{bcd}$ \\
\hline & 4.S & & $117.65 b c$ & $5.98 \mathrm{abc}$ & $1.16 \mathrm{ab}$ & $41.28 \mathrm{c}$ & $4.91 \mathrm{abc}$ & 26.24 & $1.29 \mathrm{abc}$ \\
\hline & $1 . S$ & & $134.10 \mathrm{a}$ & $5.53 \mathrm{bcd}$ & $1.31 \mathrm{ab}$ & $45.04 \mathrm{ab}$ & $4.65 \mathrm{bcd}$ & 26.79 & $1.27 \mathrm{bcd}$ \\
\hline & $2 . S$ & & $128.37 \mathrm{ab}$ & $6.76 \mathrm{ab}$ & $1.09 \mathrm{~b}$ & $45.98 \mathrm{a}$ & $5.43 \mathrm{ab}$ & 26.37 & $1.42 \mathrm{ab}$ \\
\hline Linas & $3 . S$ & & $112.30 \mathrm{~cd}$ & $4.84 \mathrm{~cd}$ & $1.14 \mathrm{ab}$ & $42.43 \mathrm{abc}$ & $3.61 \mathrm{~d}$ & 25.79 & $0.93 d$ \\
\hline & 4.S & & $105.75 \mathrm{~cd}$ & $4.62 \mathrm{~d}$ & $1.27 \mathrm{ab}$ & $41.33 \mathrm{bc}$ & $4.00 \mathrm{~cd}$ & 25.23 & $1.01 \mathrm{~cd}$ \\
\hline $\mathbf{Y} \times \mathbf{V}$ & SD & & & & & & & & \\
\hline & & 1.SD & 82.33 & 4.30 & $1.22 \mathrm{abc}$ & $34.65 \mathrm{~g}$ & $3.30 \mathrm{ef}$ & $25.55 c$ & $0.84 \mathrm{de}$ \\
\hline & & 2.SD & 92.63 & 4.88 & $1.28 \mathrm{abc}$ & 37.07efg & $4.35 b-f$ & $25.78 b c$ & $1.12 b-e$ \\
\hline & Olas & 3.SD & 94.40 & 4.15 & $1.28 \mathrm{abc}$ & $40.42 \mathrm{def}$ & $3.17 \mathrm{f}$ & $25.91 b c$ & $0.83 \mathrm{e}$ \\
\hline & & 4.SD & 98.13 & 5.52 & $1.45 \mathrm{ab}$ & $35.51 \mathrm{fg}$ & $5.03 \mathrm{bcd}$ & $26.78 b c$ & $1.34 \mathrm{bcd}$ \\
\hline & & 1.SD & 109.50 & 4.25 & $1.19 b c$ & $40.07 \mathrm{~d}-\mathrm{g}$ & $3.38 \mathrm{ef}$ & $25.30 \mathrm{c}$ & $0.85 \mathrm{de}$ \\
\hline 2018 & & 2.SD & 112.47 & 5.29 & $1.26 \mathrm{abc}$ & $40.87 \mathrm{def}$ & $4.90 \mathrm{~b}-\mathrm{e}$ & $26.96 \mathrm{abc}$ & $1.32 \mathrm{~b}-\mathrm{e}$ \\
\hline & Linas & 3.SD & 100.73 & 4.22 & $1.26 a b c$ & $42.21 \mathrm{cde}$ & $3.10 \mathrm{f}$ & $26.74 b c$ & $0.83 \mathrm{e}$ \\
\hline & & 4.SD & 100.13 & 4.87 & $1.37 \mathrm{ab}$ & 40.46def & $4.51 b-f$ & $25.82 b c$ & $1.16 \mathrm{~b}-\mathrm{e}$ \\
\hline & & 1.SD & 128.03 & 6.72 & $1.05 \mathrm{~cd}$ & $44.11 \mathrm{bcd}$ & $4.78 b-e$ & $25.33 c$ & $1.21 \mathrm{~b}-\mathrm{e}$ \\
\hline & & 2.SD & 144.30 & 9.47 & $1.51 \mathrm{a}$ & $44.30 \mathrm{bcd}$ & $7.67 \mathrm{a}$ & $29.29 a$ & $2.25 \mathrm{a}$ \\
\hline & Ulas & 3.SD & 137.60 & 7.66 & $0.84 \mathrm{~d}$ & $43.23 \mathrm{~cd}$ & $5.85 \mathrm{abc}$ & $25.92 b c$ & $1.52 b c$ \\
\hline & & 4.SD & 137.17 & 6.44 & $0.87 \mathrm{~d}$ & $47.04 \mathrm{abc}$ & $4.78 b-e$ & $25.71 b c$ & $1.23 b-e$ \\
\hline & & 1.SD & 158.70 & 6.81 & $1.44 \mathrm{ab}$ & $50.02 \mathrm{ab}$ & $5.92 \mathrm{abc}$ & $28.28 \mathrm{ab}$ & $1.68 \mathrm{ab}$ \\
\hline 2019 & I ings & 2.SD & 144.27 & 8.23 & $0.91 \mathrm{~d}$ & $51.08 \mathrm{a}$ & $5.96 \mathrm{ab}$ & $25.78 b c$ & $1.53 b c$ \\
\hline & Linas & 3.SD & 123.87 & 5.46 & $1.02 \mathrm{~cd}$ & $42.64 \mathrm{cde}$ & $4.13 c-f$ & $24.83 c$ & $1.02 \mathrm{cde}$ \\
\hline & & 4.SD & 111.37 & 4.36 & $1.17 \mathrm{bc}$ & $42.40 \mathrm{cde}$ & 3.49def & $24.64 \mathrm{c}$ & $0.86 \mathrm{de}$ \\
\hline Avera & & & 117.23 & 5.79 & 1.19 & 42.24 & 4.64 & 26.16 & 1.22 \\
\hline
\end{tabular}

Means shown by different letters within a column are significantly different. 
According to year $\mathrm{x}$ sowing date interactions, the greatest seed yield $\left(6.81 \mathrm{~g}^{-1}\right.$ plant $)$ was obtained from the $2^{\text {nd }}$ sowing date of 2019. In terms of cultivar $x$ sowing date interactions, the greatest value $\left(6.01 \mathrm{~g}^{-1}\right.$ plant $)$ was obtained from the $2^{\text {nd }}$ sowing date of Olas cultivar. According to the triple interactions, the greatest seed yield (7.67 $\mathrm{g}^{-1}$ plant) was obtained from the $2^{\text {nd }}$ sowing date of Olas cultivar in 2019. Sowing date is among the most important agricultural practices affecting seed yield of safflower. In present study, too early or too late sowing dates resulted in lower plant height, number of heads and thus lower seed yield due to unfavorable environmental conditions during the seed filling stage. In previous studies, Ozel et al. (2004), Omidi and Sharifmogadas (2010), Khalil et al. (2013) and Sahu and Thakur (2016) reported that seed yields generally decreased with delayed sowing which might be attributed to the decrease in some yield components.

\section{Oil content}

Triple (cultivar $\mathrm{x}$ year $\mathrm{x}$ sowing date) interactions had significant effects on oil contents $(\mathrm{p}<0.05)$ and the greatest value $(29.29 \%)$ was obtained from $2^{\text {nd }}$ sowing date of Olas cultivar sown in 2019 (Table 3 and 4). Oil content is not designated by a single factor. It is considered as a quantitative inherited character influenced by cultivar, climatic factors and local growing regions (Omidi et al., 2012; Baydar and Erbas, 2016). In present study, effects of different sowing dates on oil content were not found to be significant. These results supported by the findings of Samanci et al. (2001); Deltalab et al. (2011) and Keles and Ozturk (2012) who showed that oil content was not affected by sowing date.

\section{Oil Yield}

Years, sowing dates, year $\mathrm{x}$ sowing date, cultivar $\mathrm{x}$ sowing date and triple interactions had highly significant $(\mathrm{p}<0.01)$ and cultivars and year $\mathrm{x}$ cultivar interactions had significant $(\mathrm{p}<0.05)$ effects on oil yields (Table 3$)$. Oil yield was identified as $1.04 \mathrm{~g}^{-1}$ plant in the first year and $1.41 \mathrm{~g}^{-1}$ plant in the second year. Linas cultivar had significantly higher oil yield $\left(1.41 \mathrm{~g}^{-1}\right.$ plant $)$ than Olas cultivar (1.29 $\mathrm{g}^{-1}$ plant). Furthermore, year $\mathrm{x}$ cultivar interaction demonstrated that the highest oil yield $\left(1.55 \mathrm{~g}^{-1}\right.$ plant) was obtained from Olas cultivar in 2019. In terms of the sowing dates, the maximum oil yield $\left(1.55 \mathrm{~g}^{-1}\right.$ plant) was obtained from the $2^{\text {nd }}$ sowing date and no differences were seen between the other three sowing dates. Too early or too late sowing dates resulted in lower seed yields and thus lower oil yields. According to sowing date $\mathrm{x}$ year interactions, the greatest oil yield $\left(1.89 \mathrm{~g}^{-1}\right.$ plant) was obtained from the $2^{\text {nd }}$ sowing date in 2019. In terms of cultivar $\mathrm{x}$ sowing date interactions, the greatest oil yield per plant $\left(1.68 \mathrm{~g}^{-1}\right.$ plant $)$ was obtained from the $2^{\text {nd }}$ sowing date of Olas cultivar. Regarding the triple interactions, the maximum oil yield $\left(2.25 \mathrm{~g}^{-1}\right.$ plant $)$ was recorded from the $2^{\text {nd }}$ sowing date of Olas cultivar in 2019 (Table 4). In present study, oil yield per plant values ranged from 0.83 to $2.25 \mathrm{~g}^{-1}$ plant with an average of 1.22 $\mathrm{g}^{-1}$ plant. Oil yields decreased with delayed sowing dates.
These results supported the findings of Kizil (2002), Omidi and Sharifmogadas (2010) and Aslantas and Akinerdem (2019) who reported that with the delay of sowing dates, the long-day photoperiod forced plants to earlier generative phase resulting in reduced seed and oil yield. Based on the observed results, it can be concluded that with an unsuitable sowing date, the reduction of oil yield was much more related to the reduction of seed yield than oil content.

\section{CONCLUSION}

Good agronomical practices and appropriate sowing dates play a great role in high yields from safflower cultivars. Present findings are in agreement with the results of previous studies highlighting the significant effects of sowing dates on plant height, number of heads per plant, thousand seed weight, seed yield and oil yield. Present findings revealed that sowing dates did not significant effects on seed weight per head and oil content of two safflower cultivars. In terms of investigated parameters, Olas cultivar seemed to be more adaptable to ecological conditions of Samsun province. The highest values were mostly obtained from the $2^{\text {nd }}$ sowing date (14 ${ }^{\text {th }}$ November). It was concluded based on present findings that advancing or delaying sowing dates could have adverse effects on yield and yield components of safflower cultivars.

\section{ACKNOWLEDGEMENTS}

This study was financially supported by Ondokuz Mayis University (with the Project No: PYO.ZRT.1904.18.018).

\section{LITERATURE CITED}

Akhter, M.T., M.A. Mannan, P. B. Kundu and N.K. Paul. 2015. Effects of different sowing dates on the phenology and accumulated heat units in three rapeseed (Brassica campestris L.) varieties. Bangladesh J Bot. 44(1): 97-101.

ANKOM. 2017. Technology Method Analytical Procedure XT10/XT10i/XT15/XT15i http://www.ankom.com/, (Accessed January 20, 2020).

Aslantas, S. and F. Akinerdem. 2019. Effects of different sowing dates on yield, yield component and quality of some winter safflower cultivars. J Bahri Dagdas Crop Res. 9(1): 21-28.

Badri, A.R., A.S. Rad, S.S. Zadeh and Z. Bitaraftan. 2012. Sowing date effect on spring safflower cultivars. Int J Sci Adv Tech. 1(9): 26-32.

Barla, A.K., G.M. Kote and D.D. Deshmukh. 2020. Effect of sowing dates on yield and yield attributes of safflower genotypes. Int J Curr Microbiol Appl Sci. 9(1): 361-366.

Baydar, H. and S. Erbas. 2016. Line development breeding for high yield, oil and oleic acid content in safflower (Carthamus tinctorius L.). J Field Crops Central Res Ins. 25 (Special issue-2): 155-161.

Beech, D.F. and M.J.T. Norman. 1963. The effect of time of planting on yield attributes of varieties of safflower. Aust $\mathbf{J}$ Exp Agric. 3(9): 140-148.

Camas, N. and E. Esendal. 2006. Estimates of broad-sense heritability for seed yield and yield components of safflower (Carthamus tinctorius L.). Hereditas. 143: 55-57.

Carver, R. 2019. Practical data analysis with JMP. $3^{\text {rd }}$ ed. Cary NC: SAS Institute. 
Cosge, B. and M.D. Kaya. 2008. Performance of some safflower (Carthamus tinctorius L.) varieties sown in late-autumn and late-spring. J Nat Applied Sci. 12(1): 13-18.

Dajue, L. and H. Mundel. 1996. Safflower (Carthamus tinctorius L.). In: Promoting the Conservation and Use of Underutilized and Neglected Crops. 7th Edition, Institute of Plant Genetics and Crop Plant Research, Gatersleben/International Plant Genetic, Rome.

Deltalab, B., A.H Kazemi and E.B. Pasban. 2011. The effect of sowing dates on yield, yield components and oil content of three spring safflower cultivars (Carthamus tinctorius L.) under full irrigation regime in Tabriz. J Crop Ecophysio. (Agric Sci). 5(19): 11-23.

Emami, T., R. Naseri, H. Falahi and E. Kazemi. 2011. Response of yield, yield component and oil content of safflower (cv. Sina) to planting date and plant spacing on row in rainfed conditions of western Iran. Am-Eura J Agric Envir Sci. 10(6): 947-953.

Emongor, V. 2010. Safflower (Carthamus tinctorius L.) the underutilized and neglected crop: A review. Asian J Plant Sci. 9(6): 299-306.

FAO. 2019. Food and Agriculture Organization of the United Nations. http://www.fao.org/faostat/en/\#data/QC, (Accessed August 12, 2020).

Gecgel, U., M. Demirci and E. Esendal. 2007. Fatty acid composition of the oil from developing seeds of different varieties of safflower (Carthamus tinctorius L.). J Am Oil Chem' Soc. 84: 47-54.

Ghanbari-Odivi, A., H. Hashemzade, B. Bahrampour and M. Saeidi. 2013. Effect of sowing date on yield and its components, oil and protein concentration and some agronomical traits of safflower (Carthamus tinctorius L.). Tech J Eng Appl Sci. 3(14): 1405-1410.

Gomez, K.A. and A.A. Gomez. 1984. Statistical procedures for agricultural research. $2^{\text {nd }}$ ed. New York: John Wiley \& Sons.

Hatipoglu, H., H. Arslan, M. Karakus and A. Kose. 2012. Determination suitable sowing time of different safflower (Carthamus tinctorius L.) cultivars on Sanliurfa conditions. Uludag Uni J Agric Fac. 26(1): 1-16.

Hussain, T., M.A. Tariq, I. Ahmad, M. Saghir, M. Batool, M. Safdar, A. Sher and M. Tariq. 2014. Characters association analysis in safflower (Carthamus tinctorius L.). J Bio Agric Healthcare. 4(6): 63-65.

Keles, R. and O. Ozturk. 2012. Effect of different sowing dates on the seed yield and quality of safflower. Int $\mathbf{J}$ Agric Nat Sci. 5(1): 112-117.

Khalil, N.A., A.Y.M. Dagash and S.O. Yagoub. 2013. Effect of sowing date, irrigation intervals and fertilizers on safflower (Carthamus tinctorius L.) yield. Discourse J Agric Food Sci. 1(5): 97-102.

Kizil, S.A. 2002. A study on the determination of suitable sowing date of safflower (Carthamus tinctorius L.) in Diyarbakir ecological conditions. Anatolian J. 12(1): 37-50.

La Bella, S., T. Tuttolomondo, L. Lazzeri, R. Matteo, C. Leto and M. Licata. 2019. An agronomic evaluation of new safflower (Carthamus tinctorius L.) germplasm for seed and oil yields under Mediterranean climate conditions. Agronomy. 9(8): 468-473.
Mohamadzadeh, M., S.A. Siadat, M.S. Norof and R. Naseri 2011. The effects of planting date and row spacing on yield, yield components and associated traits in winter safflower under rain fed conditions. Am Eura J Agric Environ Sci. 10(2): 200-206.

Muhyedin, A., C.B. Sahin and N. Isler. 2019. Determination of yield, yield components and oil content of different safflower varieties grown under Hatay conditions, J Agric Nat. 22(5): 678-684.

Nickabadi, S., A. Solemani, S.M. Dehdashti and M. Yazdanibakhsh. 2008. Effect of sowing dates on yield and yield components of spring safflower (Carthamus tinctorius L.) in Isfahan region. Pakistan J Bio Sci. 11(15): 1953-1956.

Omidi, A.H. and M.R. Sharifmogadas. 2010. Evaluation of Iranian safflower cultivars reaction to different sowing dates and plant densities. World Appl Sci J. 8(8): 953-958.

Omidi, A., H. Khazaei, P. Monneveux, F. Stoddard. 2012. Effect of cultivar and water regime on yield and yield components in safflower (Carthamus tinctorius L.). Turk J Field Crops. 17(1): 10-15 .

Oz, M. 2016. Relationship between sowing time, cultivar, and quality in safflower. J Chem. 2016: 1-8.

Ozel, A., T. Demirbilek, M.A. Gur and O. Copur. 2004. Effects of different sowing date and intrarow spacing on yield and some agronomic traits of safflower (Carthamus tinctorius L.) under Harran Plain's arid conditions. Turkish J Agric Fores. 28(6): 413-419.

Sahu, J. and N.S. Thakur. 2016. Response of date of sowing on yield and yield attributes of safflower cultivars. The Bioscan. 11(1): 503-507.

Samanci, B., E. Ozkaynak, D. Basalma and S. Uranbey, 2001. The effects of different sowing dates on the yield and related traits of some safflower (Carthamus tinctorius L.) cultivars grown in Ankara and Antalya. Mediterian Agric Sci. 14(1): 29-32.

Samanci, B. and E. Ozkaynak. 2003. Effect of planting date on seed yield, oil content and fatty acid composition of safflower (Carthamus tinctorius) cultivars grown in the Mediterranean region of Turkey. J Agro Crop Sci. 189(5): 359-360.

Seadh, S.E., A.N.E. Attia, M.A. Badawi and S.M.S. El-Hety. 2012. Response of seed yield and its components of safflower to sowing dates, nitrogen fertilizer levels and times of foliar application with milagrow. J Biol Sci. 12(6): 342348.

Sirel, Z. and Z. Aytac. 2016. Relationships between the seed yield and some agronomic characteristics of safflower (Carthamus tinctorius $\mathrm{L}$.) under semi-arid conditions. Turk $\mathrm{J}$ Field Crops. 21(1): 110-119.

Tayebi, A., H. Afshari, F. Farahvash, S.J. Masood and S. Nezarat. 2012. Effect of drought stress and different planting dates on safflower yield and its components in Tabriz Region. Iran J Plant Physio. 2(3): 445-453.

TUIK. 2020. Turkish Statistical Institute. http://www.tuik.gov.tr/PreTablo.do?alt_id=1001, (Accessed September 21, 2020) 